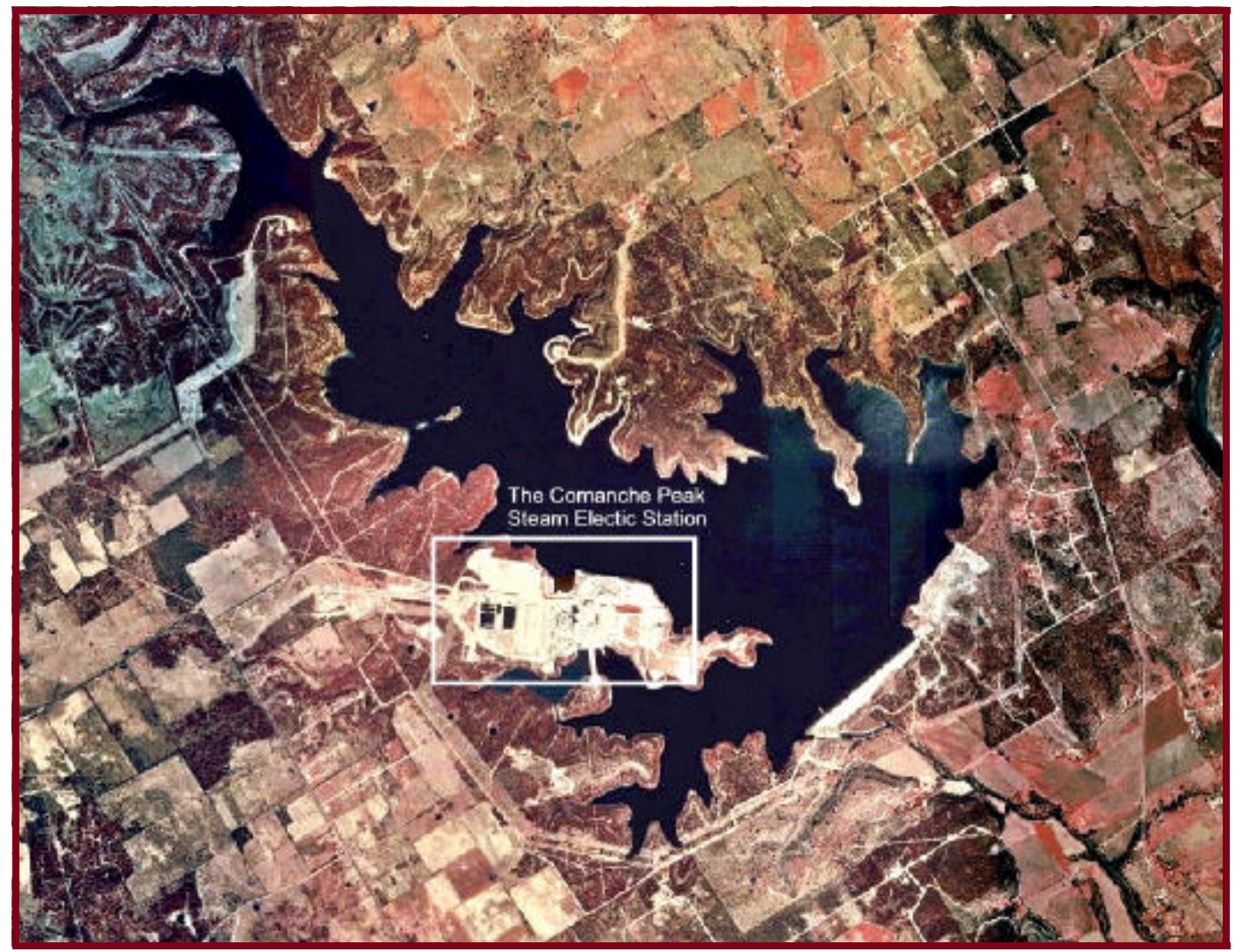

\title{
Final MTI Data Report: Comanche Peak Steam Electric Station (U)
}

Westinghouse Savannah River Company August 2002

Savannah River Site

Aiken, SC 29808

Prepared for the U. S. Department of Energy under contract no. DE-AC09-96SR18500 
This document was prepared in conjunction with work accomplished under Contract No. DE-AC09-96SR18500 with the U. S. Department of Energy.

\section{DISCLAIMER}

This report was prepared as an account of work sponsored by an agency of the United States Government. Neither the United States Government nor any agency thereof, nor any of their employees, makes any warranty, express or implied, or assumes any legal liability or responsibility for the accuracy, completeness, or usefulness of any information, apparatus, product or process disclosed, or represents that its use would not infringe privately owned rights. Reference herein to any specific commercial product, process or service by trade name, trademark, manufacturer, or otherwise does not necessarily constitute or imply its endorsement, recommendation, or favoring by the United States Government or any agency thereof. The views and opinions of authors expressed herein do not necessarily state or reflect those of the United States Government or any agency thereof.

This report has been reproduced directly from the best available copy.

Available for sale to the public, in paper, from: U.S. Department of Commerce, National Technical Information Service, 5285 Port Royal Road, Springfield, VA 22161, phone: (800) 553-6847, fax: (703) 605-6900

email: orders@ntis.fedworld.gov

online ordering: http://www.ntis.gov/help/index.asp

Available electronically at http://www.osti.gov/bridge

Available for a processing fee to U.S. Department of Energy and its contractors, in paper, from: U.S. Department of Energy, Office of Scientific and Technical Information, P.O. Box 62, Oak Ridge, TN 37831-0062,

phone: (865)576-8401,

fax: (865)576-5728

email: $\underline{\text { reports@ adonis.osti.gov }}$ 


\title{
Final MTI Data Report: Comanche Peak Steam Electric Station (U)
}

\author{
Prepared by \\ M. J. Parker and A. J. Garrett \\ Westinghouse Savannah River Company \\ Aiken, South Carolina 29808
}

August 2002 
WSRC-TR-2002-00374

Final MTI Data Report: Comanche Peak Steam Electric Station (U)

Savannah River Technology Center

This page intentionally left blank. 


\section{TABLE OF CONTENTS}

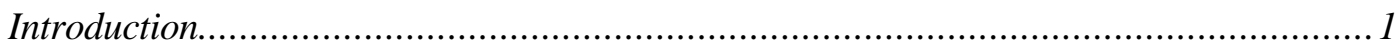

Surface Water Temperature Measurements ...................................................... 1

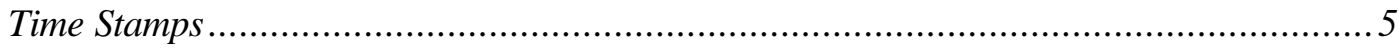

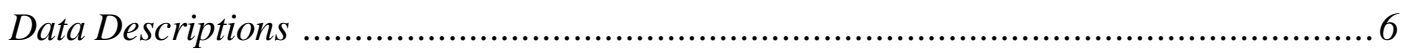

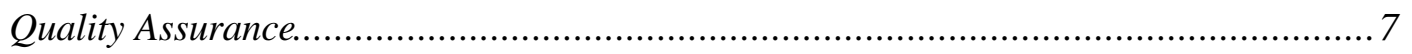

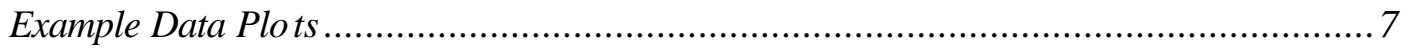

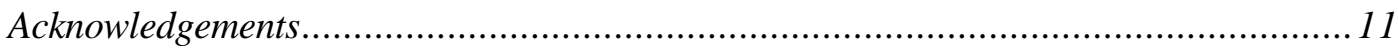

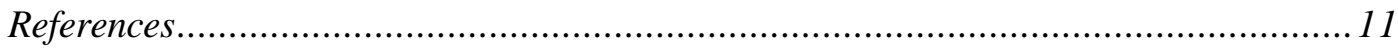

\section{LIST OF F IGURES}

Figure 1. The Comanche Peak Nuclear Power Station ............................................... 1

Figure 2. The Surface Water Temperature Monitoring Site Locations ........................2

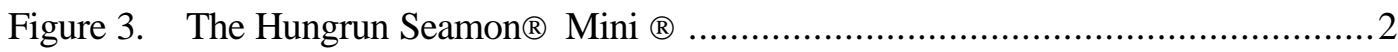

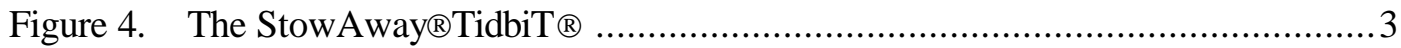

Figure 5. Initial Water Temperature Sensor Deployment...................................... 3

Figure 6. Images of Deployment Locations for March-April 2002 ............................4

Figure 7. Time Series Plot of Water Temperature Data Collected............................ 8

Figure 8. Water Temperature Measurements .................................................. 8

Figure 9. Example of Wind Direction Data Collected …......................................... 9

Figure 10. Example of Wind Speed Data Collected ............................................

Figure 11. Example of Air Temperature Data Collected ........................................... 10

Figure 12. Example of Plant Water Intake and Outfall Temperatures........................... 10

Figure 13. Example of Plant Power Data …............................................................ 11 
WSRC-TR-2002-00374

Final MTI Data Report: Comanche Peak Steam Electric Station (U)

Savannah River Technology Center

\section{LIST OF TABLES}

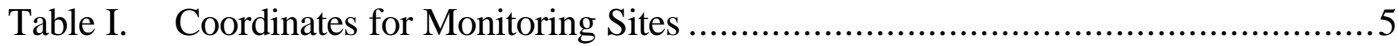

Table II. Descriptions of Data Nomenclature................................................... 6 


\section{INTRODUCTION}

During the periods from May 2000 to September 2001 and March 5 to April 10, 2002, cooling-lake surface water temperature data was collected at the Comanche Peak Nuclear Power Station near Granbury, Texas (Figure 1). This effort was led by the Savannah River Technology Center (SRTC) with the assistance of plant personnel. Permission for setting up these monitoring sites was granted by TXU Energy, which owns the plant site and surrounding property including Squaw Creek reservoir where the measurements were taken. This work was done in support SRTC's ground truth mission for the US Department of Energy's Multispectral Thermal Imager (MTI) satellite (Garrett, et al, 1999). Data described in this report are available from the authors (contact information provided at the end of report).
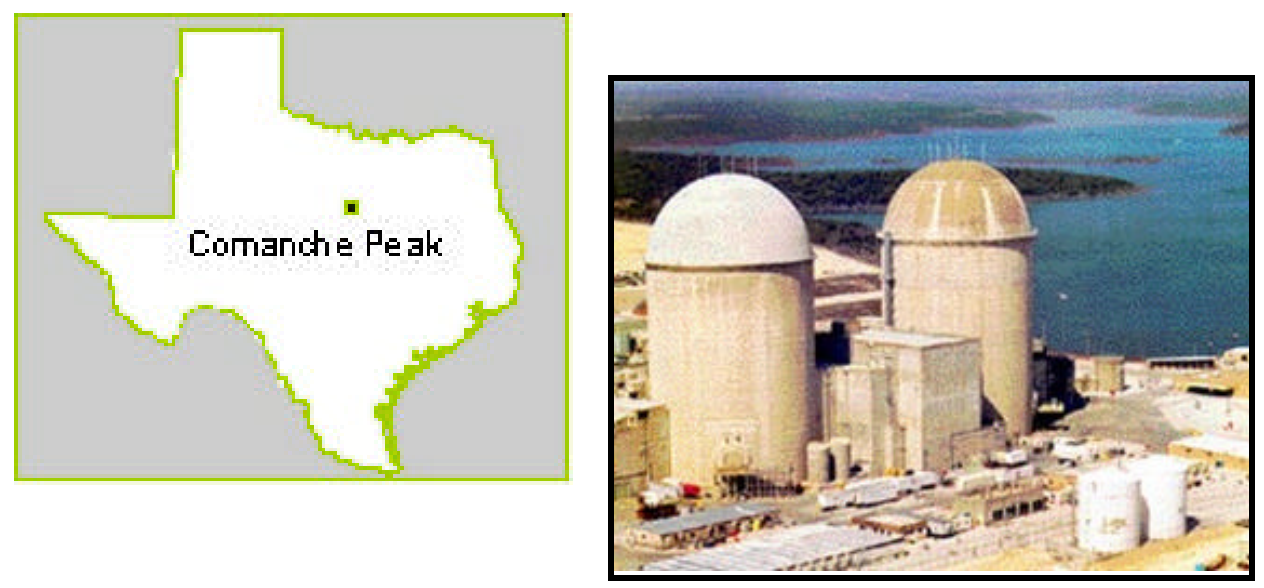

Data

described

in

this

report

are

available

from

Figure 1. The Comanche Peak Nuclear Power Station near Granbury, Texas.

\section{Surface Water Temperature Measurements}

inree monitoring sites, in the warmtwater aiscnarge now (snown as "OBL"), at the plant water intake (shown as "Intake"), and in a so-called safe shutdown impoundment (shown as "SSI") were used and are shown in Figure 2. These locations were intended to capture temperature extremes of the lake at any given time. Unfortunately, the amount of data collected was less than expected due to frequent loss of sensors (vandalism and excessive corrosion) or flotation problems, which failed to keep the sensors properly submerged.

In light of the lack of data a month-long field campaign was conducted during the period from March 5 to April 10, 2002 to collect more extensive sur- 
face water temperature data. With able support from plant personnel, ten monitoring sites were installed (Figure 2) to capture the overall temperature distribution of the lake. These sites are shown as: "SSI", "IO", "OBL", "Bubbler Buoy", "Alternate Lake Discharge", "A", "B", "C", and "D". This period also coincided with an unusual orbit of MTI whereby the same location could be consecutively imaged for about two weeks. One hundred percent data recovery was attained for the period.

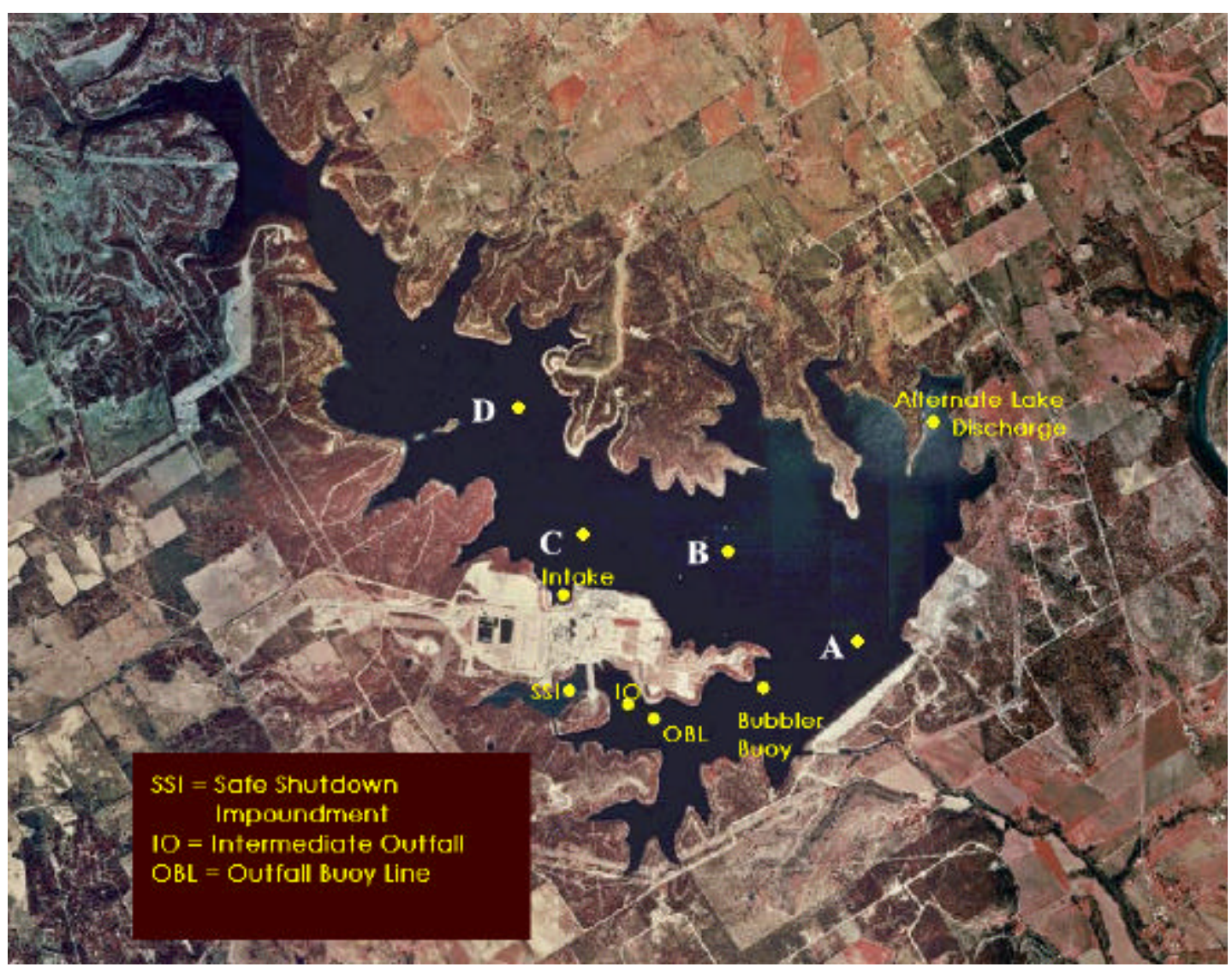

Figure 2. Surface water temperature monitoring site locations.

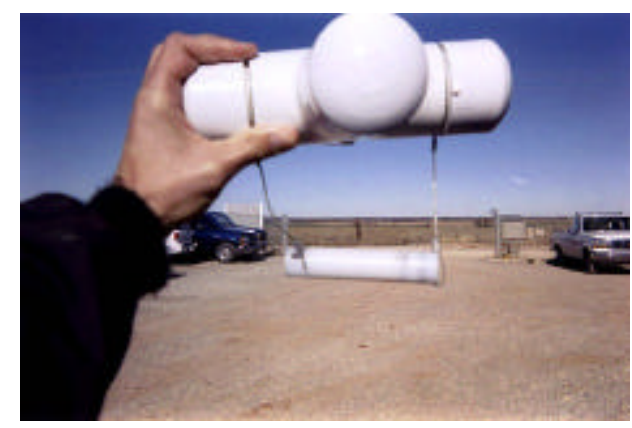

Figure 3. The Hugrun Seamon ${ }^{\circledR}$ Mini ${ }^{\circledR}$ suspended from a float before deployment. 


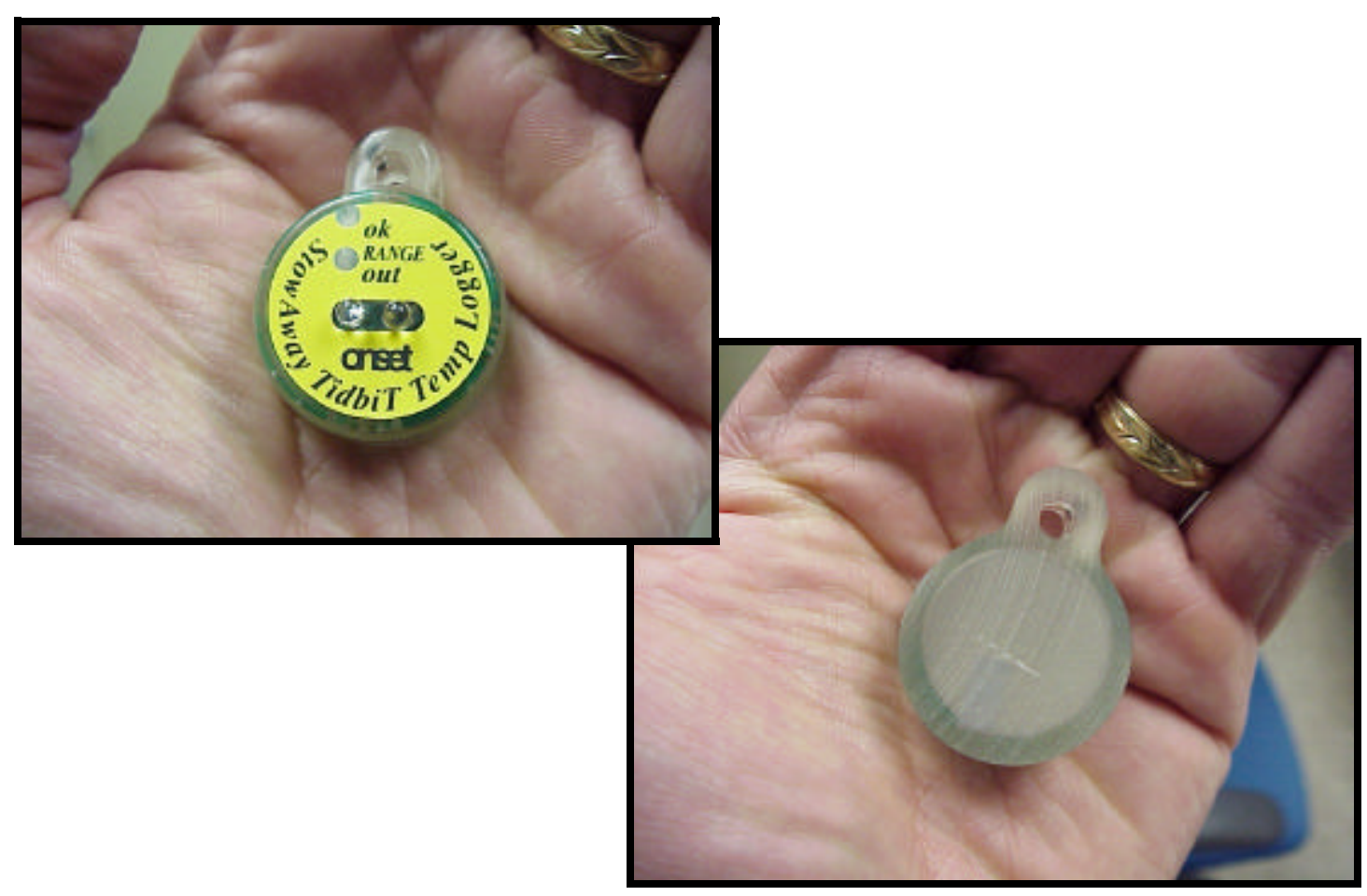

Figure 4. The StowAway ${ }^{\circledR}$ TidbiT ${ }^{\circledR}$ (front view, left, and rear view, right).

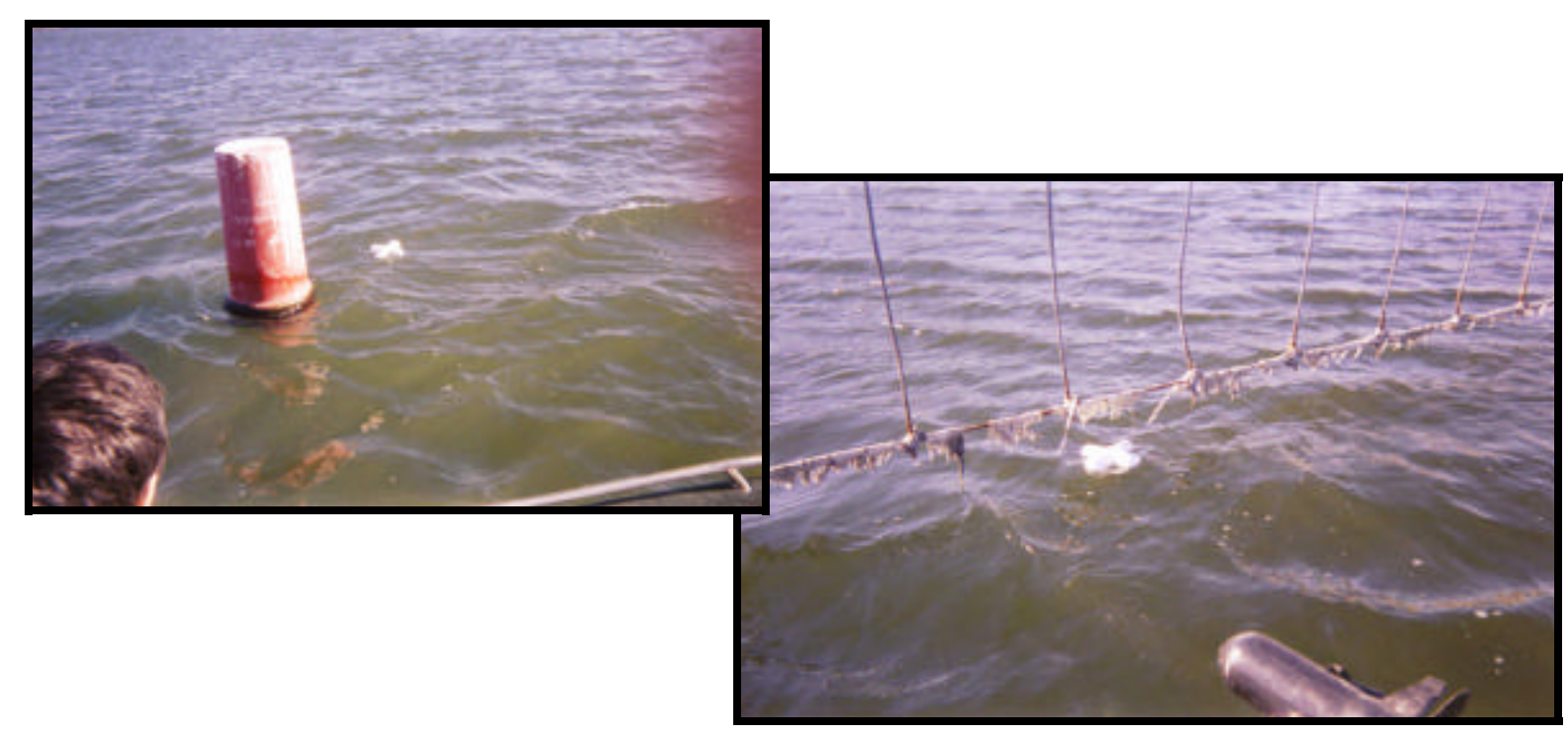

Figure 5. Initial water temperature sensor deployment at the outfall buoy line $(O B L)$, left, and at the plant water intake fence, right. 
WSRC-TR-2002-00374

Final MTI Data Report: Comanche Peak Steam Electric Station (U)

Savannah River Technology Center

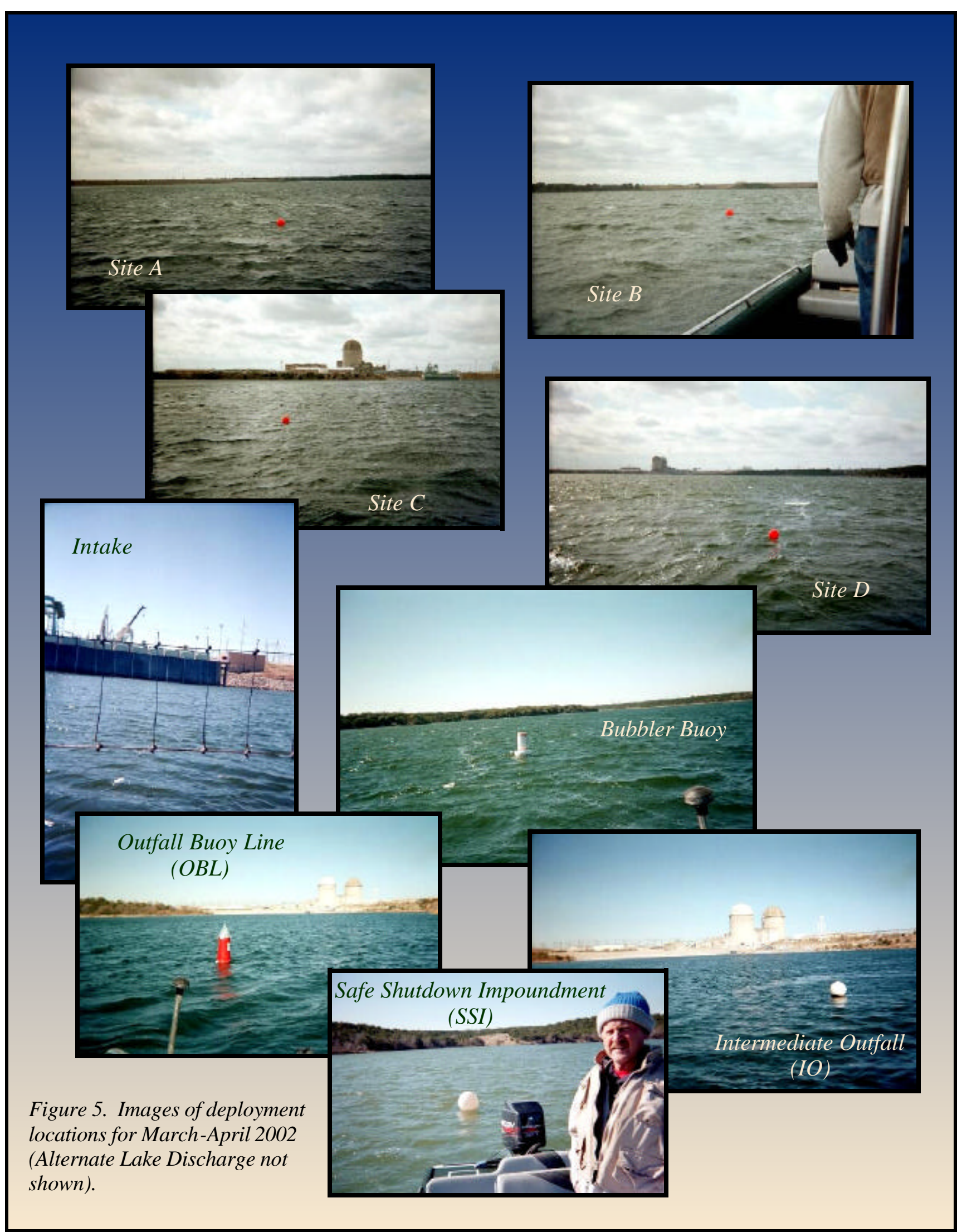

August 2002 
Table I. Coordinates for Monitoring Sites

Site
Safe Shutdown Impoundment (SSI)
Intermediate Outfall Buoy (IO)
Outfall Buoy Line (OBL)
Bubbler Buoy
Alternate Lake Discharge
Intake
A
B
C
D

Coordinates (WGS-84)

N32.29378, W97.7865

N32.2930, W97.7806

N32.2920, W97.7783

N32.2941, W97.7687

N32.3144, W97.7531

N32.3016, W97.7866

N32.2976, W97.7601

N32.3047, W97.7717

N32.3062, W97.7848

N32.3157, W97.7905

Additionally, Comanche Peak personnel supplied plant operating and meteorological data for the entire period of study. These data were merged with the water temperature data and are stored in a spreadsheet (see "Data Description", page 6).

\section{TIME STAMPS}

Data were collected with time stamps corresponding to local Eastern (Standard or Daylight) Time for the May 2000 - September 2001 period. Greenwich Mean Time (GMT) was used for the March 5 - April 10, 2002 period. Time stamps associated with the surface water temperatures were used as the time stamp for all data. Given this requirement, the meteorological and plant operating data that most closely corresponded with the time stamp of the surface water temperature data were merged as though they had an identical time stamp. In the majority of cases, the actual difference between the various data types was less than 1015 minutes making relevant comparisons appropriate. All Hugrun Seamon ${ }^{\circledR}$ Mini ${ }^{\circledR}$ data were collected at hourly intervals, all StowAway® TidbiT® were collected at 30 minute intervals except for the March 5 - April 10, 2002 data which were collected at 15 minute intervals.

Plant operating data were sub-sampled to correspond to the water temperature data, and the meteorological data are reported as hourly averages. 


\section{DATA DESCRIPTION}

The following table summarizes the headings in the file called QA_CP.xls (available from the authors), which contains surface water temperature data, meteorological data, and plant operating data.

Table II. Description of Data Nomenclature

\section{SURFACE WATER TEMPERATURES}

$\underline{\text { Name }}$

Intake

Discharge

Impoundment

\section{Description (All temperatures ${ }^{\circ} \mathrm{C}$ )}

Surface water temperature near the plant water intake Surface water near the warm-water discharge outfall Surface water temperature in the plant safe shutdown impoundment

\section{PLANT OPERATING DATA READINGS}

$\underline{\text { Name }}$

T2400A

T2401A

T2402A

T2403A

T2404A

T2404A

Q2851A

Q0340A

U3477

(Waste power)

(Estimated flow

from power)

(Estimated

inlet temperature)

(Estimated

outlet temperature)

(Estimated flow from outlets)

\section{$\underline{\text { Description }}$}

Cooling water inlet A-1 temperature $\left({ }^{\circ} \mathrm{C}\right)$ Cooling water inlet A-2 temperature $\left({ }^{\circ} \mathrm{C}\right)$ Cooling water outlet A-3 temperature $\left({ }^{\circ} \mathrm{C}\right)$ Cooling water outlet A-4 temperature $\left({ }^{\circ} \mathrm{C}\right)$ Cooling water outlet B-3 temperature $\left({ }^{\circ} \mathrm{C}\right)$ Cooling water outlet B-4 temperature $\left({ }^{\circ} \mathrm{C}\right)$

Power variability (MW) Electric power output (MW) Reactor thermal output (MW) Calculated from U3477 - Q0340A (MW)

Calculated flow (m3/s)

Calculated inlet temperature $\left({ }^{\circ} \mathrm{C}\right)$

Calculated outlet temperature $\left({ }^{\circ} \mathrm{C}\right)$

Calculated from inlet and outlet data (m3/s) 


\section{SURFACE WATER TEMPERATURES}

Name

\section{Description (All temperatures ${ }^{\circ} \mathrm{C}$ )}

A

Alternate Lake

Discharge

B

Bubbler Buoy

C

D

Impoundment

Intake Fence

Intermediate

Outfall

Outfall Buoy

Line
Surface water temperature at location A near the dam

Surface water temperature in bay where water is transported from Lake Granbury

Surface water temperature at location B offshore from a plant maintenance building

Surface water temperature at buoy demarcating a deep water bubbler system

Surface water temperature at location $\mathrm{C}$ offshore from the plant water intake

Surface water temperature at location D offshore from the state park

Surface water temperature in the plant safe shutdown impoundment

Surface water temperature near the plant water intake Surface water temperature nearest the warm-water discharge outfall

Surface water temperature in the warm-water discharge fall

\section{QuAlity ASSurance}

Data quality assurance was performed on all surface water temperature measurements. Time series plots of data were reviewed for obvious outliers or other problematic data. Problematic data were deleted and appear as blanks within the data files.

\section{Example Data Plots}

The following figures show examples of data plotted from the quality assured spreadsheet (QA_CPxls). 
WSRC-TR-2002-00374

Final MTI Data Report: Comanche Peak Steam Electric Station (U)

Savannah River Technology Center

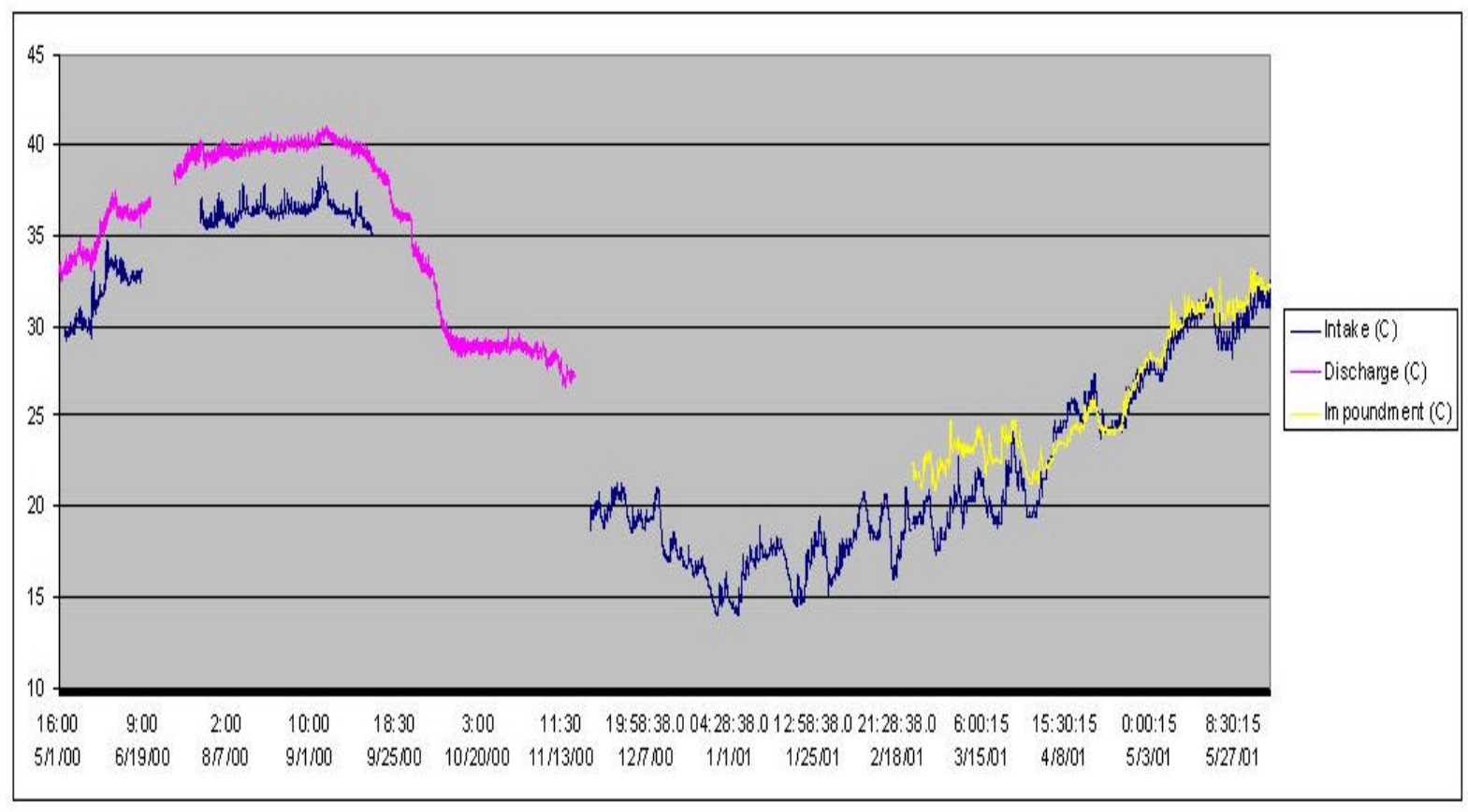

Figure 7. Time series plot of water temperature data collected during the May 2000-May 2001 period. Note the lengthy periods of missing data for all locations. The Impoundment (SSI) location was not installed until early 2001.

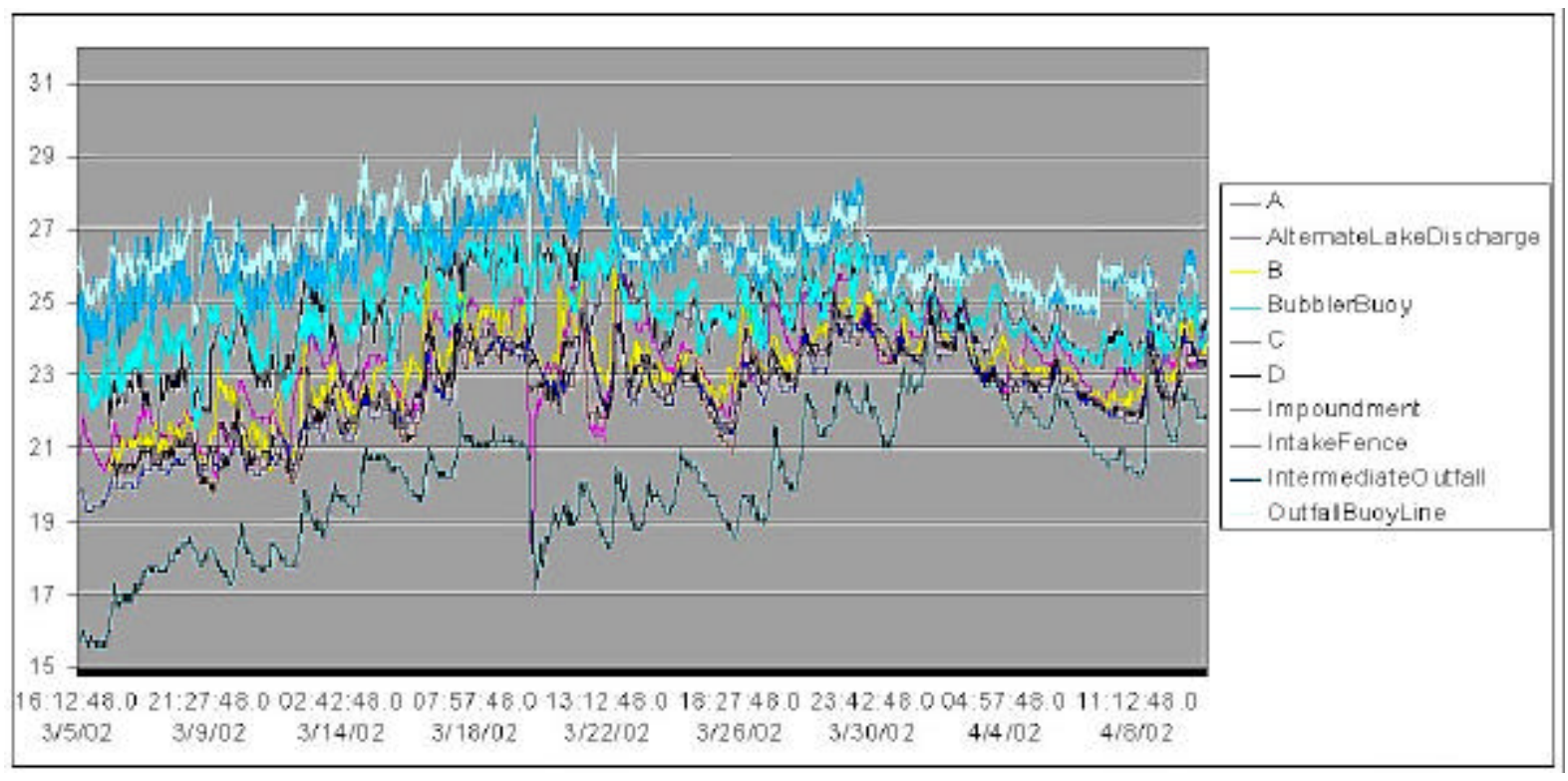

Figure 8. Water temperature measurements during the March-April 2002 period. 


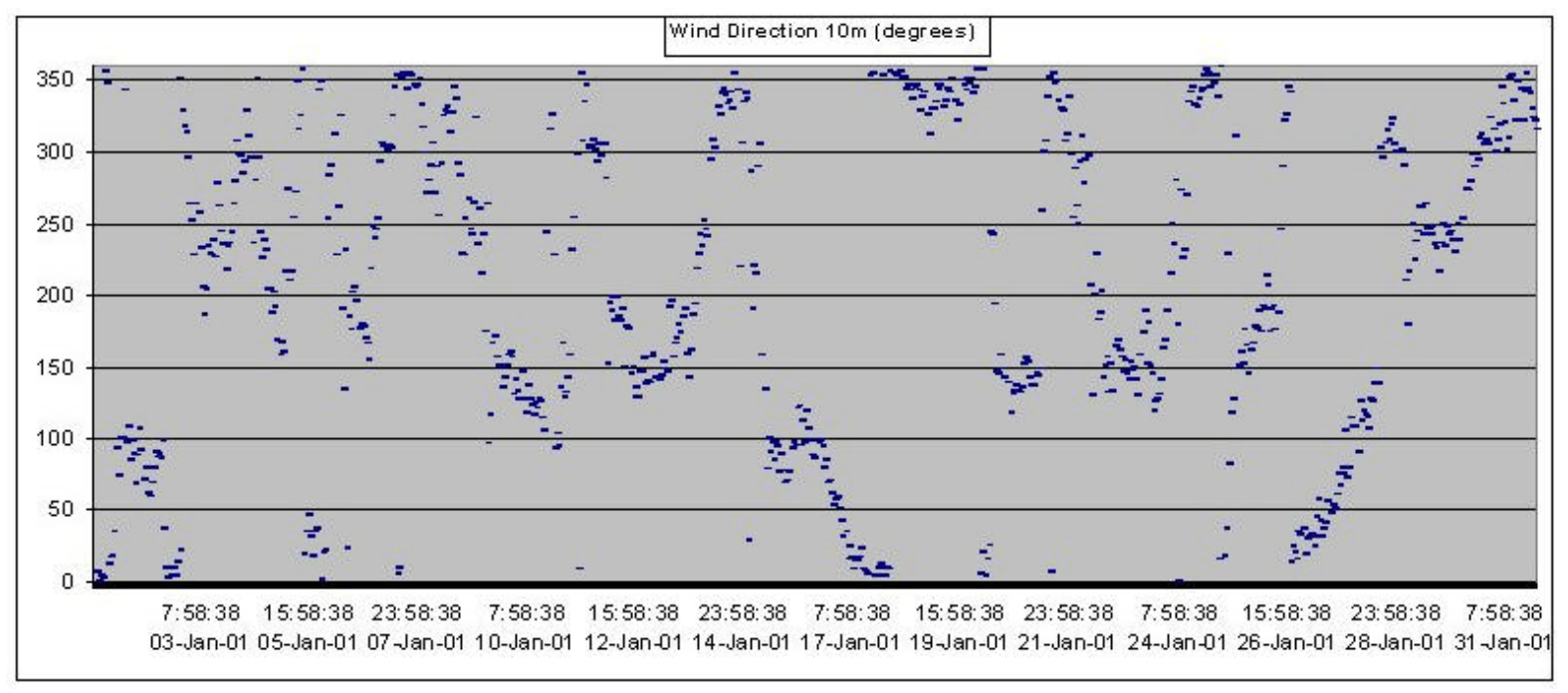

Figure 9. Example of wind direction data collected at $10 \mathrm{~m}$ on the Comanche Peak tower in January 2001.

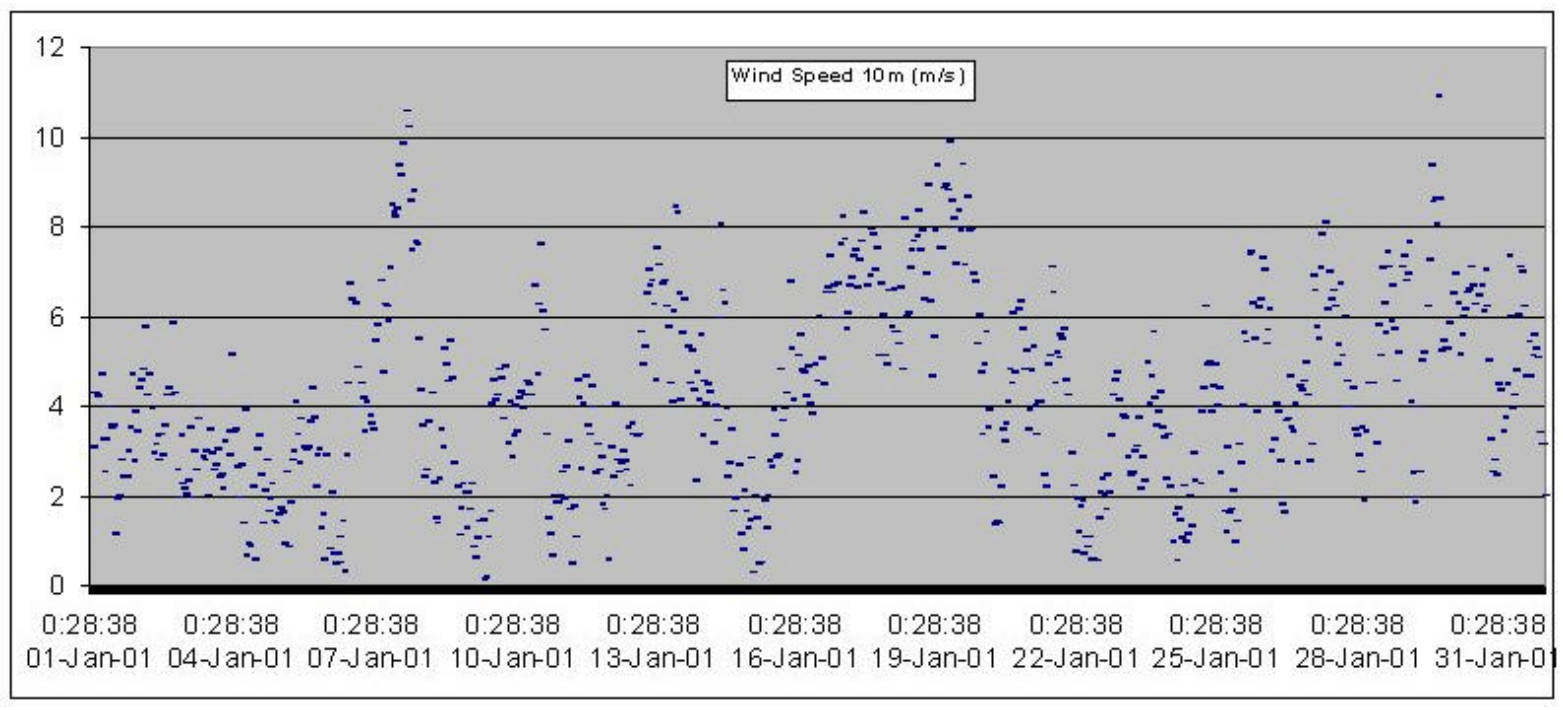

Figure 10. Example of wind speed data collected at $10 \mathrm{~m}$ on the Comanche Peak tower in January 2001. 
WSRC-TR-2002-00374

Final MTI Data Report: Comanche Peak Steam Electric Station (U)

Savannah River Technology Center

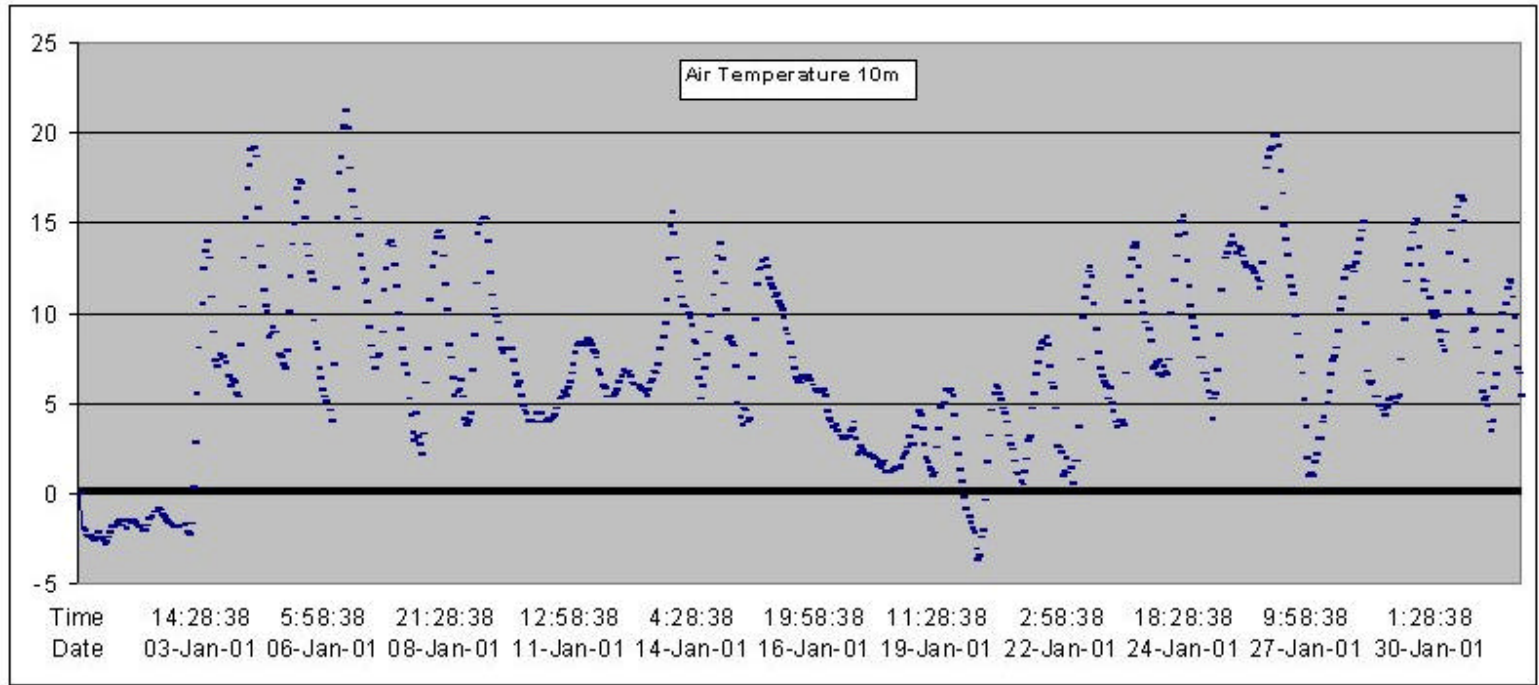

Figure 11. Example of air temperature data collected at 10 meters on the Comanche Peak tower in January 2001.

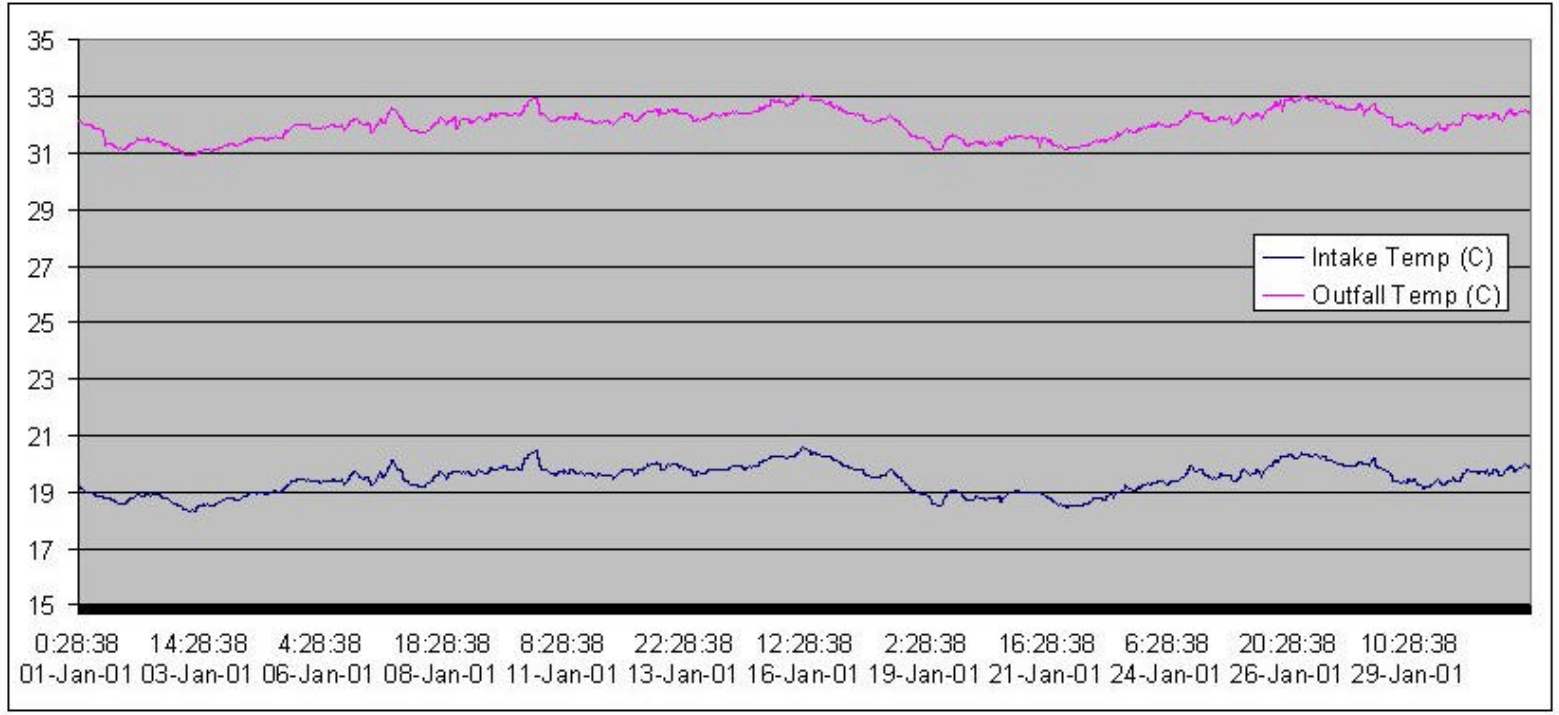

Figure 12. Example of plant water intake and outfall temperatures for January 2001. 


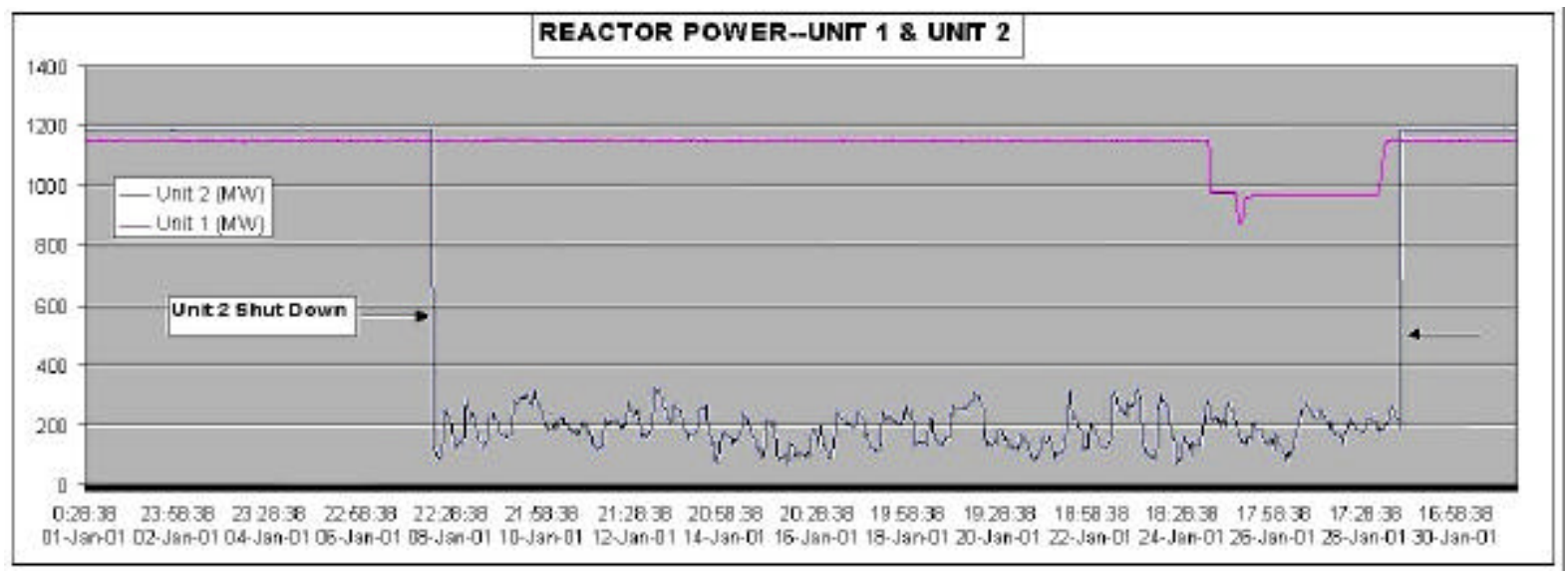

Figure 13. Example of plant power data for January 2001. Note the period where Unit 2 was shut down

\section{ACKNOWLEDGEMENTS}

Special thanks to Gordon Dalby, Bruce Turner, and Don Doan of TXU Energy for providing dedicated support to data collection efforts and for supplying plant operating and meteorological data. Thanks also to Kuo-Fu Chen of SRTC for assisting with data quality assurance.

\section{REFERENCES}

Garrett, A. J., R. J. Kurzeja, B. L. O’Steen, M. J. Parker, M. M. Pendergast, and E. VillaAleman, 1999: Ground-Truth Measurements Plan for the Multispectal Thermal Imager (MTI) Satellite. WSRC-TR-99-00455. Westinghouse Savannah River Company, Aiken, SC. 